Miller (2018)

\title{
ANSERJ
}

Vol. 9, No. 2

Autumn / Automne 2018

pp. $23-40$

Canadian Journal of Nonprofit and Social Economy Research

Revue canadienne de recherche sur les OBSL et l'économie social

\section{Nonprofit Strategic Management Revisited}

\author{
Eric W. Miller \\ George Mason University
}

\begin{abstract}
This article presents a review and analysis of empirically based research on strategic management in nonprofit organizations appearing in peer-reviewed journals between 1998 and 2015, and compares these findings with an earlier, similar study to determine how nonprofit use of strategic management has evolved over time. Findings suggest that determinants of strategic management have evolved beyond funder requirements to include environmental pressures to increase organizational efficiency and effectiveness, professionalize staff capacities, and respond to changing customer requirements. Nonprofits continue to use strategic management in response, and have recently adopted a wide range of for-profit strategies and practices in both strategy content and strategy performance areas. Strategic management offers both risks and rewards for nonprofits, but requires significant time, resources, and human capital that not all nonprofits readily possess.
\end{abstract}

\section{RÉSUMÉ}

Cet article présente l'évaluation et l'analyse de recherches empiriques-parues entre 1998 et 2015 dans des revues évaluées par les pairs-sur la gestion stratégique d'organismes à but non lucratif. II compare ces données avec une étude antérieure similaire afin de déterminer comment la gestion stratégique par les organismes à but non lucratif a évolué. Les résultats suggèrent que les déterminants de la gestion stratégique ont progressé au-delà des besoins des subventionneurs, tenant compte aujourd'hui des pressions environnementales pour accroître l'efficience et l'efficacité organisationnelles, professionnaliser le personnel et répondre aux besoins changeants de la clientèle. Dans ces circonstances, les organismes à but non lucratif continuent de recourir à la gestion stratégique et ont récemment adopté un vaste éventail de stratégies et pratiques à but lucratif dans les domaines du contenu et de la performance stratégiques. La gestion stratégique, tout en posant certains risques, offre incontestablement des récompenses aux organismes à but non lucratif, mais elle requiert un temps, des ressources et une main d'œuvre que les organismes à but non lucratif ne possèdent pas forcément.

KEYWORDS / MOTS CLÉS Nonprofit organization; Strategic management; Strategy formulation; Strategy content; Strategy implementation; Organizational management / Organisme à but non lucratif; Gestion stratégique; Formulation de stratégies; Contenu de stratégies; Mise en place de stratégies; Gestion organisationnelle 


\section{Miller (2018)}

\section{INTRODUCTION}

Nonprofit organizations (NPOs) are highly dependent on their external environment and vulnerable to effects from financial shocks, rapid technological change, and evolving stakeholder pressures (Bryson, 2011; Froelich, 1999). A common approach nonprofits use to address these changes and the resulting organizational challenges is strategic management (Black, Hinrichs, \& Fabian, 2007; Mara, 2000). Strategic management can help nonprofits not only manage and respond to environmental change but also improve organizational decision-making (Maranville, 1999), help manage organizational relationships and external interactions (Hafsi \& Thomas, 2005), drive goal accomplishment, and improve performance (Alexander, 2000). ${ }^{1}$ Understanding how and where to apply strategic management is, therefore, critically necessary in allowing NPO leaders and managers to successfully navigate the environment and accomplish their missions.

To assist both practitioners and researchers in the application and advancement of strategic management, a team of researchers in 1999 consolidated a fragmented field of research to create the first comprehensive literature review on nonprofit strategic management. Melissa Stone, Barbara Bigelow, and William Crittenden (1999) synthesized 65 journal articles on nonprofit strategic management between 1977 and 1997 and discovered that most nonprofits had not yet adapted some form of strategic planning, and those that had were driven by funder requirements and the desire to shift missions and organizational roles. Strategic management was mostly used in response to resource requirements, with little concern for customer preferences and demand, and the outcomes of strategic efforts predominantly hinged on the structures, leaders, and networks within a given nonprofit (Stone et al., 1999). Over the past two decades, these findings have widely influenced both practitioner and scholarly efforts to better understand and apply strategic management; the article's citation count is in the 80th percentile for similar articles (Elsevier, 2016a) and has an above-average fieldweighted citation impact of 1.34 (Elsevier, 2016b).

In the two decades since the study by Stone and colleagues (1999) (referred to hereafter as the SBC study), however, nonprofit organizations have been buffeted by unprecedented environmental and operating challenges, including the economic crises of the early 2000s and 2008, revolutionary advancements in technological and digital capabilities, and evolutionary changes in demographic, social, and economic relationships. Governments, the primary source of funding for many NPOs, have been steadily decreasing grants and contributions to nonprofits (Alexander, 2000; Papadimitriou, 2007), leading to increased competition between NPOs, which are not accustomed to competing with rivals (Basinger \& Peterson, 2008; Hackler \& Saxton, 2007; Shea \& Hamilton, 2015). Increasing digitization and the availability of public data have created pressure for NPOs to improve transparency, accountability, and organizational effectiveness (ChadwickCoule, 2011; Golensky \& Mulder, 2006). These external pressures disrupt how nonprofits operate and deliver social value and, further, how and where NPOs can best use strategic management to navigate a changing environment.

As a result, what was true regarding strategic management in nonprofit organizations in the last two decades of the 20th century may not still be true in the first two decades of the 21st century. Since the SBC study, there has been very little work that consolidates recent empirical evidence on how nonprofits may have evolved the use of strategic management to achieve organizational goals. A new synthesis of the literature is needed and has even been suggested by current researchers (Kong, 2008). This study attempts to accomplish such a synthesis to determine if, and how, strategic management in nonprofits has evolved over the past two decades. Comparing the results between the SBC synthesis and this new synthesis may help answer the following questions:

Q1: How are nonprofit organizations using strategic management to change or improve how they operate and perform? 


\section{Miller (2018)}

Q2: How are nonprofits using strategic management to achieve organizational goals?

Q3: Are there any new or emerging issues with nonprofit strategic management practice?

The first section in this article provides the context for research, the following section explores the conceptual framework of strategic management used in this study, and the third section highlights the research methodology. The fourth section compares findings between this study and the SBC study, and the final section summarizes current and emerging trends in nonprofit strategic management.

\section{STRATEGIC MANAGEMENT}

Strategic management in nonprofit organizations can refer to a range of organizational management applications. Mary Louise Hatten (1982) describes strategic management as "the process which determines and maintains a viable set of relationships between the organization and its environment" (p. 90), and Michael Olsen, Eliza Tse, and Joseph West (2008) use "the ability of management ... to properly align the firm with the forces driving change in the environment in which the firm competes." (p. 6). John Bryson (2011) includes the achievement of organizational goals, stating strategic management is "the reasonable integration of strategic planning and implementation across an organization in an ongoing way to enhance the fulfillment of mission, meeting of mandates, continuous learning, and sustained creation of public value" (p. 25). Across the varying definitions, however, the use of strategic management is generally thought to help NPOs achieve positive effects, including the ability to improve communications and establish paths to accomplish goals (Hatten, 1982), improve program offerings (McHatton, Bradshaw, Gallagher, Reeves, 2011), prosper in dynamic environments (Hoffman, Digman, \& Crittenden, 1991), build organizational capacity (Bryson, 2011), and achieve long-run superior performance (Kong, 2008).

Separating the strategic management process into phases enables a more specific examination of the various activities with the process. This article adopts the SBC study approach of analyzing strategic management through the phases of formulation, content, and implementation, as originally presented by Stephen Shortell, Ellen Morrison, and Shelley Robbins (1985). Strategy formulation is "the process an organization uses to determine its direction over the long term to meet its mission and achieve its objectives (Tucker, Thorne, \& Gurd, 2013, p. 112). Strategy content "encompasses the actions and tactics that compose an organization's strategy and includes corporate, business, and functional level strategies (Stone et al., 1999, p. 380). Strategy implementation is the "process of turning strategy into action and monitoring and assessing the results" (Gimbert, Bisbe, \& Mendoza, 2010, p. 479).

The SBC study further conceptualized a framework for analyzing these strategic management phases through determinants, outcomes, and performance (see Figure 1). Determinants of strategy are factors, influences, or conditions that exist within the organization or in the external environment that serve as antecedents or drivers of strategic management efforts. Outcomes of strategic management include observed changes, processes, or effects within the organization, or in external engagements, relationships, or conditions. The performance of strategic processes refers to a nonprofit's ability to acquire the resources necessary to achieve strategic objectives, a critical dependency for organizational survival (Crittenden, Crittenden, Stone, \& Robertson, 2004). Both the SBC study and this study use the strategic management analysis framework to align and report study results.

Figure 1: Strategic management organizing framework

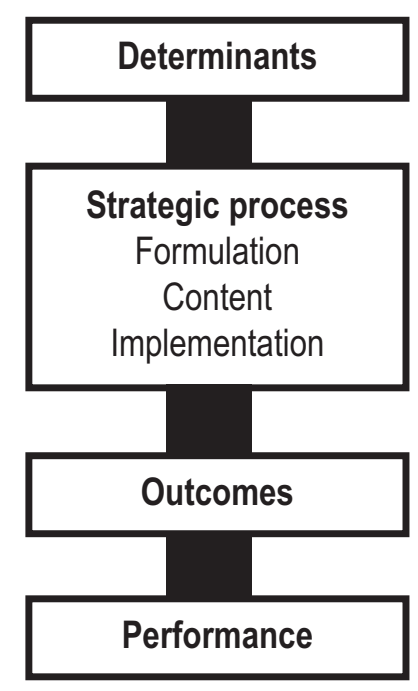

Note: Adapted from Stone et al., (1999) 


\section{Miller (2018)}

\section{METHOD}

This research synthesis replicates the SBC study's approach to examining nonprofit strategic management, adopting the same strategic management process view and partitioning the literature between strategy formulation, content, and implementation. One significant departure from the SBC study, however, was in the search and selection of literature. The SBC study searched only the most prominent management journals and journals focused on nonprofit management between 1977 and 1997; this study used database searches to broaden the available pool of research, by both publication source and geographical location. Searches for "strategic management" AND "nonprofit organizations" were conducted in 33 electronic databases, including Business Source Complete, Complementary Index, Academic Search Complete, PyscINFO, SocINDEX, and JSTOR Journals. Only empirical articles in peer-reviewed academic journals between 1998 and 2015 that addressed one of the three strategic management phases were included in the review. The SBC study used 66 articles from 18 different journals; in contrast, this study used 58 articles from 20 journals (see Appendix A for a complete listing of journals).

Results and findings in the articles were extracted using Nvivo, a software program designed to organize and support the analysis of qualitative or unstructured data sets. This data was organized by the orientation of the original research to one of the strategic process phases, and then divided and aligned along the three dimensions of determinants, outcomes, and performance. Thematic synthesis was used, a method of review for qualitative and quantitative research through which descriptive themes are developed and then translated into analytic themes that respond to a research question (Thomas \& Harden, 2008). These analytic themes were aligned in the same organizing framework as the SBC study to better compare the results of both studies. The following description of results outlines the changes in nonprofit strategic management for each of the three phases, organized by the dimensions of determinants, content, and performance.

\section{RESULTS}

Analysis of 58 articles over the past two decades indicates nonprofit use of strategic management has widely grown, driven by two main forces: pressure from stakeholders to achieve greater efficiency and effectiveness, and pressure from customers to adapt products and services to changing demands. Nonprofits have responded to these pressures by both adopting strategic management practices and adapting organizational strategies. To a very limited extent, nonprofits have further attempted to instill greater performance measurements systems to track and demonstrate social impact.

\section{Strategy formulation: Then and now}

Between 1977 and 1997, NPOs that did conduct strategy formulation were largely driven by organizational characteristics, the need to agree on organizational goals, and funder requirements. The SBC study further found strategy formulation efforts affected changes in organizational missions, structures, and the roles of boards and NPO managers, but discovered little evidence to connect strategy formulation to performance. Informed by 19 of 58 articles, this study found that funder requirements can still drive strategy formulation, but so too does a NPO's desire to grow or scale the organization, adapt to changing client demands, and respond to funder demands for increased accountability and transparency. Results also suggest NPOs use strategy formulation to determine organizational goals and objectives, shift approaches to delivering goods and services, and strengthening manager and employee relationships. Like the SBC study, little evidence connects strategy formulation to performance. Table 1 highlights the major findings between the SBC study and this study for strategy formulation. 
Miller (2018)

Table 1: A comparison of major findings on strategy formulation, 1977-2015

\begin{tabular}{|l|l|l|}
\hline \multicolumn{1}{|c|}{$1977-1997$} & \multicolumn{1}{|c|}{ 1998-2015 } \\
\hline $\begin{array}{l}\text { Most nonprofits have not adopted strategic } \\
\text { management }\end{array}$ & Strategic management & $\begin{array}{l}\text { Most nonprofits conduct some form of strategic } \\
\text { management }\end{array}$ \\
\hline $\begin{array}{l}\text { Organizational size, characteristics of boards and } \\
\text { management, agreement on goals, and funder } \\
\text { requirements }\end{array}$ & Determinants & $\begin{array}{l}\text { Desire for organizational growth, demand for increased } \\
\text { transparency, } n \text { response to changing client needs, and } \\
\text { competition for funding }\end{array}$ \\
\hline $\begin{array}{l}\text { Changes in mission, structure, and board and } \\
\text { management roles }\end{array}$ & Outcomes & $\begin{array}{l}\text { Determination of goals and objectives, shifts in } \\
\text { approaches to delivering goods/services, and changes } \\
\text { to manager and employee relationships }\end{array}$ \\
\hline $\begin{array}{l}\text { Relationship between planning and performance is } \\
\text { unclear but possibly associated with growth and } \\
\text { who the stakeholders are }\end{array}$ & Performance & $\begin{array}{l}\text { Recogntion exists of the need to tie strategy to } \\
\text { performance, but few nonprofits are able to do so }\end{array}$ \\
\hline
\end{tabular}

Strategy formulation: Determinants revisited

External pressures drive NPOs to use strategy formulation in response to changes in customer needs and adapt the provision of products or services NPOs provide (Inglis \& Alexander, 1999). Customers may demand that existing services offer greater value or benefit (McHatton et al., 2011), and David Moxley (2004) noted that consumer aspirations often shape how NPOs provide valued services, driving organizations to conduct strategy formulation (Crittenden et al., 2004). Further, nonprofits are experiencing additional competition for donors and funds (Alfirevic \& Gabelica, 2007; Finley, Rogers, Napier, \& Wyatt, 2011) from both nonprofit and for-profit organizations (Shea \& Hamilton, 2015). Funder demands for increased transparency have also driven nonprofits to demonstrate increased accountability (Chadwick-Coule, 2011), and to operate more in the manner of for-profit companies (Maranville, 1999).

An internal desire for organizational growth is another principal determinant for many nonprofits to conduct strategy formulation. Growth presents new management challenges for organizations, and nonprofits are turning to strategy formulation as a technique for achieving growth goals (Bryson, Gibbons, \& Shaye, 2001). Some nonprofits use strategy formulation to help develop new markets and funding sources, and ensure growth is matched to development goals (Harris, 2011). Organizational capacity growth, such as incorporating information technology tools and practices, also requires planning to ensure new capabilities are implemented to maximum utility (Jäger \& Beyes, 2010).

\section{Strategy formulation: Outcomes revisited}

Strategy formulation tools and approaches appear to help nonprofits focus and rationally determine organizational goals and priorities (Courtney, Marnoch, \& Williamson, 2009). Such tools and processes help NPOs develop plans with measurable annual goals (Mara, 2000), refine existing mission statements (Krug \& Weinberg, 2004), or develop long-term organizational plans (Finley et al., 2011; McHatton et al., 2011). One study found that nonprofits prioritized not only missions but also objectives for human capital and organizational development (Shea \& Hamilton, 2015).

Formulation efforts also alter the tactics, programs, or approaches nonprofits use to deliver products or services. In some cases, nonprofits have shifted approaches to include policy or lobbying efforts that complement local development actions (Bryson et al., 2001). Several organizations expanded services to new regions or more narrowly tailor existing services (Finley et al., 2011; Medley \& Akan, 2008). Other NPOs are incorporating engagement and outreach activities with communities and clients (Swanson, 2013). Strengthened organizational capacity is often cited as an outcome in internal de- 
cision processes (Maranville, 1999; Meerman \& Huyser, 2014), organizational strategizing (Jäger \& Beyes, 2010), strategic perspective building (Harris, 2011), and human capital development (Bryson et al., 2001).

Organizationally, strategy formulation appears to have great impacts on management and employee relationships. Several NPOs use formulation processes to build strong cultures or protect certain ethos within the organization (Chadwick-Coule, 2011; Harris, 2011; Jäger \& Beyes, 2011), or reassess and change existing cultures (Moxley, 2004). Further, strategy formulation helps create a clearer or more focused understanding of the work assigned to each employee (Chadwick-Coule, 2011; McHatton et al., 2011). Lastly, strategy formulation processes enable the reconciliation of organizational identities (Harris, 2011) and the protection of key employee and stakeholder relationships (Jäger \& Beyes, 2011).

\section{Strategy formulation: Performance revisited}

Only two studies in this review directly examine the relationship between strategy formulation and various measures of performance. Roger Courtney, Gordon Marnoch, and Arthur Williamson (2009) find that housing associations using strategy formulation are positively associated with higher levels of performance, as measured by growth, financial reporting, resource acquisition, efficiency, and customer service. Further, organizations with more sophisticated strategic management efforts and superior performance tend to be larger nonprofits. William Crittenden, Victoria Crittenden, Melissa Stone, and Christopher Robertson (2004) find little linkage between planning and performance in terms of resource acquisition, but note the positive perception by NPO managers of other, non-resource outcomes. Several other studies recognize the need for performance to follow from specific actions or tactics included in strategic planning, even if these relationships are not specifically examined.

\section{Strategy content: Then and now}

The SBC study found nonprofit strategy content was largely a response to the external funding environment and relationships with funders, while customer needs were only minimally considered. Nonprofit organizations engaged in both competitive strategies, which pursued new revenue streams, and cooperative strategies, which helped link the organization with partners to achieve mission or resourcing goals. The SBC uncovered no examination of strategy content and performance linkages. In this review, 23 of 58 articles primarily examined strategy content, and while NPOs are still vulnerable to external funding environments, stakeholder pressure further pushes nonprofits to professionalize staff activities and achieve greater efficiency, effectiveness, and transparency. In addition, changing customer needs has significantly increased as a determinant in NPO strategy content. Nonprofits have responded to these pressures by implementing a variety of strategies, including those borrowed from traditionally for-profit marketing, differentiation, and performance management strategies. Findings suggest nonprofits are increasingly connecting strategy content with the organization's

\section{Table 2: A comparison of major findings on strategy content, 1977-2015}

\begin{tabular}{|l|l|l|}
\hline \multicolumn{1}{|c|}{$1977-1997$} & \multicolumn{1}{|c|}{$1998-2015$} \\
\hline $\begin{array}{l}\text { Characteristics of resource environments and } \\
\text { existing funder relationships; Little attention to } \\
\text { changing demands for services or shifts in client } \\
\text { needs }\end{array}$ & Determinants & $\begin{array}{l}\text { Demands to improve efficiency and effectiveness, } \\
\text { professionalize NPO workforce and respond to changing } \\
\text { client needs }\end{array}$ \\
\hline $\begin{array}{l}\text { Both competitive and cooperative strategies are } \\
\text { pursued, with substantially different outcomes }\end{array}$ & Outcomes & $\begin{array}{l}\text { Nonprofits are adopting a wide range of for profit } \\
\text { corporate strategies, delivering both rewards and risks }\end{array}$ \\
\hline & Performance & $\begin{array}{l}\text { Some nonprofits use strategies to drive resource } \\
\text { acquisition, with varying success }\end{array}$ \\
\hline
\end{tabular}




\section{Miller (2018)}

ability to achieve additional funding. Table 2 highlights the major findings between the SBC study and this study for strategy content.

Strategy content: Determinants revisited

As the SBC study similarly found, strategy content is largely driven by a series of environmental pressures. Decreased government spending and increased competition are key determinants in forcing nonprofits to act (Canet-Giner, Fernandez-Guerrero, \& Peris-Ortiz, 2010) to improve the efficiency and effectiveness of operations and demonstrate improved accountability (Akingbola, 2006; Golensky \& Mulder, 2006). This drives some nonprofits to make transparency and evaluation key components of their strategic content. One nonprofit describes the environment as an "era of heightened scrutiny" (Hackler \& Saxton, 2007, p. 474) resulting from the increasing availability and access of public data. Greater access to data allows stakeholders to directly evaluate nonprofit operations and performance and subsequently pressure nonprofits to demonstrate both programmatic and fiscal accountability within their operations (Golensky \& Mulder, 2006). Further, many donors and funders require nonprofits to demonstrate improvements in efficiency and effectiveness to maintain funding (Alexander, 2000).

Even though nonprofits traditionally rely on volunteers, organizations are feeling pressure to professionalize their workforce as part of organizational strategy (Canet-Giner et al., 2010; Golensky \& Mulder, 2006). This can include professionalizing broad management practices (Alexander, 2000; Hackler \& Saxton, 2007), adopting for-profit corporate practices, or improving the training and skills of nonprofit managers. Strategies may also have more specific professionalization efforts, for example, urging nonprofits to develop a specific skill set and implement related activities (Pope, Isely, \& Asamoatutu, 2009). In either case, nonprofits are often challenged to locate and hire or train enough skilled workers to meet this pressure (Pietroburgo \& Wernet, 2004).

In addition to pressure from governments and funders, nonprofit organizations are responding to greater demands from customers and clients of associated products and services (Akingbola, 2006). The economic downturn following the financial crisis in 2007-2008 resulted in demand for an increased volume of services provided (Cronley \& Kim, 2014; Hackler \& Saxton, 2007). In some cases, the demand arises from existing clients who require additional or different types of services (Crittenden, 2000) for which there is simply not enough nonprofit supply. Other nonprofits report demand from unserved populations (Pietroburgo \& Wernet, 2004), but often face challenges in acquiring resources or assets necessary to expand existing coverage.

\section{Strategy content: Outcomes revisited}

Nonprofits employ a variety of strategy types, including adaptive strategies (Alexander, 2000), survival strategies (Golensky \& Mulder, 2006), acquiring new capabilities (Hackler \& Saxton, 2007), shifting organizational decision-making (Hafsi \& Thomas, 2005), or restructuring (Pietroburgo \& Wernet, 2004). Nonprofits also often borrow from traditional for-profit strategies and tactics to improve operational effectiveness and mission accomplishment. Marketing strategies are a common approach, but are often directed at funders and stakeholders rather than customers (Alexander, 2000; Pietroburgo \& Wernet, 2004). Mergers between organizations are used, especially if similar organizations operate in overlapping geographic regions (Basinger \& Peterson, 2008). One U.K.-based nonprofit used a strategic positioning strategy to align core missions between the activities of other nonprofits and the government (Chew \& Osborne, 2009). Resource centres, geographically distributed sites that logistically and materially facilitate the efforts of multiple nonprofit projects, have been used with success in some nonprofits (Netting, Williams, \& Hyer, 1998). And organizations with a greater lobbying or grassroots approach are trying new communications strategies (Dreiling, Lougee, Jonna, \& Nakamura, 2008). 
Internal organizational forces often shape and effect how these strategies are developed and approved. Human relationship concerns, including the amount and level of communication regarding strategies and access to information (Basinger \& Peterson, 2008), the views and commitment of employees (Cronley \& Kim, 2014; Hafsi \& Thomas, 2005), and institutional relationships (Stater, 2009) all affect the successful adoption of strategic content. In one example, a decentralized planning effort resulted in the emergence of new initiatives from employees (Canet-Giner et al., 2010). Employee involvement and engagement, however, can also reveal disagreement over the mission of the nonprofit and the desired strategic approach (Crittenden, 2000; Hafsi \& Thomas, 2005; Wollebaek, 2009), or expose challenges in navigating the existing structure of organizational decision-making (Pietroburgo \& Wernet, 2004; Pijl \& Sminia, 2004; Wollebaek, 2009). Often, the success of strategy content efforts hinge on the receptivity and involvement of employees in strategic processes.

Strategy content: Performance revisited

A handful of studies briefly mention the role of strategy content in driving performance and achieving the resources required to survive. Some NPOs simply expect individuals in the organization, in lieu of strategic management, to achieve and improve resource acquisition. Although relying on individuals for resources is not new (McMurtry, Netting, \& Kettner, 1991), nonprofits are increasingly relying on board members to connect the organization to new donors, funding sources, and political officials that might proffer support (Alexander, 2000). In addition to leveraging nonprofit boards, increasing the ability of staff to evaluate financial sources and provide financial projections can help nonprofits more accurately predict needs and secure resources (Crittenden, 2000). Organizationally, at least two strategic content choices can result in resource acquisition: linkages established between nonprofits engaged in boundary-spanning strategies can yield grants, contracts, donated services, referred clients, and media attention (Alexander, 2000), and mergers between nonprofits can ensure the financial survival of one or more nonprofits (Basinger \& Peterson, 2008).

\section{Strategy implementation: Then and now}

The SBC study found that shifts in culture and environmental forces drove nonprofits to strategy implementation efforts, as did the various characteristics and backgrounds of an organizations' leader, board, or managers. The outcomes of implementation efforts were highly influenced by organizational systems, communications, and networks, and little to no evidence was found of resulting performance effects. Sixteen of the 58 articles included in this study focused primarily on strategy implementation, and results indicate that determinants of strategy implementation have shifted from broad, external forces to specific nonprofit stakeholders, who are demanding increased accountability, efficiency, and transparency from NPOs through the development and use of performance management or measurement systems. Table 3 highlights the major findings between the SBC study and this study for strategy implementation.

Table 3: A comparison of major findings on strategy implementation, 1977-2015

\begin{tabular}{|l|l|l|}
\hline \multicolumn{1}{|c|}{$1977-1997$} & \multicolumn{1}{|c|}{$1998-2015$} \\
\hline $\begin{array}{l}\text { Exogenous turbulence affects organizational } \\
\text { structure and the relationship between strategy \& } \\
\text { structure; Leader behaviour, the structure of } \\
\text { authority, values, and their interaction }\end{array}$ & Determinants & $\begin{array}{l}\text { External pressure to improve efficiency and } \\
\text { effectiveness, competition for resources, and the } \\
\text { availability of management control mechanisms }\end{array}$ \\
\hline $\begin{array}{l}\text { Interorganizational systems or networks are critical } \\
\text { to strategy implementation outcomes }\end{array}$ & Outcomes & $\begin{array}{l}\text { Most asscociated with organizational decision making to } \\
\text { track and measure performance }\end{array}$ \\
\hline & Performance & $\begin{array}{l}\text { The linkage between performance and funding is well } \\
\text { appreciated but poorly studied, measured, or specified }\end{array}$ \\
\hline
\end{tabular}




\section{Miller (2018)}

Strategy implementation: Determinants revisited

Nonprofits are using strategy implementation in response to stakeholder pressure and competition for resources. Donors and funders increasingly expect nonprofits to demonstrate that they are being managed both efficiently and effectively (Arvidson \& Lyon, 2014) and to be transparent about their efforts (Greiling \& Stötzer, 2015; LeRoux \& Wright, 2010; Marlin, Ritchie, \& Geiger, 2009). Stakeholders require evidence of improved management through a variety of processes, including mechanisms of organizational control (Keyt, 2001; Tucker \& Parker, 2013), the introduction of performance management systems (Greiling \& Stötzer, 2015), performance measurement systems (Sheehan, 1999), and staff professionalization (LeRoux \& Wright, 2010). Additionally, strategy implementation helps some nonprofits respond to sector competition as traditional funding sources $d$ windle. Nonprofits see strategy implementation as a way to demonstrate positive performance as they compete for funds (Kaplan, 2001; Marlin, Geiger, \& Ritchie, 2013), and in many cases, funders are using strategy implementation as an evaluation criteria when awarding funds (Tucker \& Parker, 2013).

Larger or more developed nonprofits appear to more successfully use and implement strategic implementation processes. In one study, organizational size was the most significant factor in determining performance success, where larger and more developed nonprofits performed better (Brown \& Iverson, 2004). At least some evidence suggests the efforts and performance of the organization's staff specifically leads to increased financial performance (Brown \& Iverson, 2004) and successful strategy implementation (Sheehan, 1999). Other findings identified larger boards of directors as leading to more strategic and conceptual actions, and one study identified an executive director's experience and education level as significant to strategy implementation (LeRoux \& Wright, 2010).

\section{Strategy implementation: Outcomes revisited}

Strategy implementation is mostly used to measure or track performance in the organization. Funders, and to a lesser extent the Board of Directors, tend to have the most influence in both the use and focus of performance measurement systems (Fine, Thayer, \& Coghlan, 2000; Herman \& Renz, 1999), and these systems are more often found in larger nonprofits over smaller ones (Greiling \& Stötzer, 2015). Performance measurement efforts generally do not include any industry standards or benchmarks common within a nonprofit's operating sector (LeRoux \& Wright, 2010), as the resulting systems or programs are often purpose-built for a specific nonprofit's mission.

Nonprofits employ a wide variety of techniques to develop or track performance measures (Fine et al., 2000). Measures can be drawn from organizational products developed earlier in the strategy management process, such as vision statements or strategic objectives (Keyt, 2001), and translated into outcome metrics. More commonly, nonprofits use the balanced scorecard technique to track measures (Kaplan, 2001). When executed well, such processes have had great effect, including strengthening organizational commitment (Black et al., 2007), empowering managers and delineating their roles and responsibilities (Sharp \& Brock, 2012), aligning strategy, communication, and actions (Tucker \& Parker, 2013), reducing organizational costs and improving customer satisfaction (Kaplan, 2001), and improving managerial decision-making (LeRoux \& Wright, 2010).

\section{Strategy implementation: Performance revisited}

Scant research exists identifying the direct effects of strategy implementation in acquiring resources, although the importance of performance measures to gain funding is frequently noted. Dorothy Greiling and Sandra Stötzer (2015) suggest that nonprofits are keenly aware of the impact of performance accountability on securing financial resources, and Dan Marlin, Scott Geiger, and William Ritchie (2013) note that hospitals understand the "strategic imperative" (p. 427) for philanthropic donations and found hospital foundation strategies are one way to deliver. 


\section{Miller (2018)}

\section{DISCUSSION}

The findings of this synthesis indicate that nonprofit strategic management practice has indeed evolved over the past two decades, largely to adapt to changing environmental conditions and accomplish organizational goals. Broadly, although NPOs still face pressure from funders regarding performance and social impact, nonprofits are increasingly expected to improve management, in both operations and staffing, and respond to changing customer needs. Nonprofits have adapted to these expectations and adopted a wide variety of strategies and performance management approaches to achieve organizational goals, but frequently face challenges when attempting to do so. More specifically, comparing these results to the original SBC study provides some answers to the questions posed earlier in this article.

\section{Q1: How are nonprofit organizations using strategic management to change or improve how they operate and perform?}

Operations: Efficiency and effectiveness

The greatest change in environmental forces has been increased pressure to improve the efficiency and effectiveness within nonprofit management and operations. Kunle Akingbola (2006) provides the clearest explanation of these terms, citing efficiency as "relating the numbers of people served to dollars directed to programs," and effectiveness as "measurable success at resolving social problems" (p. 268). Research evidence provides at least four strategic management proposals as ways NPOs can achieve both. First, Mohammed Mahmoud and Baba Yusif (2012) recommend NPOs become both market-oriented organizations and learning organizations. Nonprofits can become market-oriented by fostering the collection and evaluation of information on various stakeholders, customers, and understanding their interests, needs, and problems. To become a learning organization, NPOs must act on this information by planning, adapting, and implementing programs to address these myriad needs. Darrene Hackler and Gregory Saxton (2007) advise NPOs to incorporate greater levels and application of information technology (IT). Although some NPOs increasingly use IT capabilities (Golensky \& Mulder, 2006), unleashing the full potential of IT capabilities may assist NPOs with efficiency, improving record keeping, performance management, and growing the networking activities of the organization (Hackler \& Saxton, 2007). Third, Martha Golensky and Cray Mulder (2006) echo earlier studies that suggest NPOs' leaders become boundary spanners, where systems are developed to internally manage NPOs and shape or buffer organizational interactions with the external environment. Finally, both Malin Arvidson and Fergus Lyon (2014) and Fine et al. (2000) suggest improved performance management or program evaluation as mechanisms to better track changes in efficiency and effectiveness.

\section{Staffing: Professionalization and volunteer recruitment}

Strategic management practices are also affecting how nonprofits staff their organizations. Stakeholders, especially funders, are pressing for the professionalization of NPO staff. Few nonprofits, however, have the capacity and resources to hire salaried workers to replace the myriad of volunteers that support NPOs. In lieu of hiring salaried or "professional" employees, NPOs have responded by improving staff training opportunities and more purposefully recruiting volunteers. Organizations that are strengthening internal training for staff and volunteers report improvements in volunteer performance and internal coordination (Golensky \& Mulder, 2006), more effective operations with improved accountability (Alexander, 2000), and more developed individual competencies and greater decentralization of decision-making, resulting in faster action and response times (Canet-Giner et al., 2010).

In addition to internal training, a few NPOs are testing new approaches to recruiting volunteers. One nonprofit offers flexible staffing arrangements to accommodate volunteer needs and cross-level organizational workloads (Pietroburgo \& Wernet, 2004). Others have advocated for using marketing approaches for recruitment. Some nonprofits already use marketing strategies for a variety of consumer-focused or mission-related purposes, but the same marketing resources could also focus on potential volunteers as another target market (Pope et al., 2009). Although internal training and tar- 


\section{Miller (2018)}

geted recruitment appear to have positive outcomes for many NPOs, the expertise required to sufficiently employ IT capabilities and systems, for example, often overwhelms volunteers, and NPOs have found that salaried professionals are necessary in IT roles (Hackler \& Saxton, 2007).

\section{Performance: Changing customer demands}

Strategic management appears to help nonprofits increasingly accommodate and respond to changing customer demands, in contrast to the findings of the earlier SBC study. Broadly, nonprofits acknowledge the need to include customer and community inputs when conducting strategic management (Akingbola, 2006; Crittenden, 2000). One survey of 242 NPO boards found that "responding to community needs" (Inglis \& Alexander, 1999, p. 160) was a nonprofit board's greatest responsibility. Some nonprofits are implementing IT improvements to help improve service quality for customers (Cronley \& Kim, 2014) or track the number and type of customers served (Hackler \& Saxton, 2007). Other NPOs are incorporating direct feedback from customers in planning phases using surveys (McHatton et al., 2011; Moxley, 2004).

\section{Q2: How are nonprofits using strategic management to achieve organizational goals?}

The adaptation of strategies ... but with risks

Through strategic management, nonprofit organizations are adopting a variety of traditional strategies or adapting forprofit strategies to fit their needs (Mahmoud \& Yusif, 2012), and lines distinguishing between nonprofits and for-profits are increasingly blurred (Baruch \& Ramalho, 2006; Beck, Lengnick-Hall, \& Legnick-Hall, 2008; Brown \& Iverson, 2004; Tucker, Thorn, \& Gurd, 2013). The adoption of traditionally for-profit strategy content may reflect pressure from stakeholders, who may have more experience in for-profit settings, and view the adoption as a natural evolution of nonprofits (Tucker \& Parker, 2013). Alternatively, nonprofits may also seek out proven best practices when pursuing improved business models or developing performance management systems, and for profits offer a variety of approaches to choose from (Finley et al., 2011).

Nonprofits can benefit from adapting for-profit strategies. The very process of developing strategy content can help focus the organization (Crittenden, 2000). Expanding services, improving business techniques, and networking activities have resulted in a greater exchange of skills between organizations, stronger external support from stakeholders, and the development of wider networks (Akingbola, 2006; Alexander, 2000). Partnering with corporate volunteers can yield both additional human capital and perspectives (Samuel, Wolf, \& Schilling, 2013). At least one nonprofit reported that these strategic adaptations led "to some surprising levels of control over the environment" (Hafsi \& Thomas, 2005, p. 343).

Even as NPOs attempt traditional or for-profit strategies, organizations face both constraints and risks when attempting to employ strategy content. The original founders of nonprofits, especially if they are still involved in the organization, may resist shifting or expanding the services they helped to establish (Alexander, 2000). Stakeholders may also resist, concerned that expansion may duplicate existing programs or reduce the impact of existing efforts (Alexander, 2000, Golensky \& Mulder, 2006; Hafsi \& Thomas, 2005). Nonprofit boards can also block changes even after changes are well underway (Pietroburgo \& Wernet, 2004), and any changes that required structural shifts may move out experienced workers or board members (Neville \& Murray, 2008). Employees and volunteers may also resist if proposed changes seem to clash with the organization's mission, or if new strategies require different human capital skill sets (Basinger \& Peterson, 2008). Further, organizational shifts and changes in strategies can be lengthy and labour intensive, sapping already strained resources (Alexander, 2000; Pope et al., 2009), or require additional resources when strategies are exceedingly successful in accomplishing organizational goals (Netting et al., 1998). 


\section{Miller (2018)}

\section{Q3: Are there any new or emerging issues with nonprofit strategic management practice? Performance management systems}

As part of the strategic management process, nonprofits are increasingly pursuing mechanisms to assess and measure performance outcomes. Performance management approaches or systems are often required by funders, but NPOs themselves increasingly see value in measuring impact to attract additional resources or moral support, demonstrate a return on investment, or simply to see if their theory of change to solving a social issue is working (Pritchard, Ogain, \& Lumley, 2012). Even NPOs with existing measurement systems often seek improved approaches, as initial or traditional methods of tracking performance become obsolete (Keyt, 2001).

Nonprofit organizations often develop innovative, unique, or purpose-built products and services to fill a social need. As Akingbola (2006) states, "there is no universally accepted measure of organizational performance, especially one similar to for-profits" (p. 267). The uniqueness of each NPO's context in delivering social products and services often necessitates a similarly unique or customized way to measure performance or impact. Custom-built performance measurement systems can be incredibly time-consuming to develop and implement, and the organization must be trained in using and understanding the system. The use of custom systems means nonprofits, broadly, implement a wide variety of performance management systems, which are not easily transferred between organizations or sectors or adaptable to even similar NPOs (Fine et al., 2000). Although nonprofits realize the data generated by these performance systems is necessary for resource acquisition or required by funders, many organizations would rather allocate such administrative investments into mission-oriented goals (Greiling \& Stötzer, 2015). This can generate organizational resentment or resistance against fully using performance measurement systems and the data they can provide.

Nonetheless, practitioners increasingly see value in performance measurement as a management tool beyond a mere funding requirement. Unfortunately, practitioners may not always have the time or resource available to either adapt forprofit tools or develop custom measurements for their organization. When attempting to use performance measurement to improve efficiency and effectiveness, as has been suggested, it is probable that efficiency and effectiveness will each require a unique measurement approach. Further evidence or research that can effectively demonstrate the application of sustainable for-profit measurement tools, or create broadly applicable methods specific to the nonprofit sector, is likely to greatly assist and inform NPO managers in performance management approaches.

\section{Resource requirements for strategic management}

Strategic management requires a significant investment of organizational will, capacity, and resources to conduct strategic management phases, develop performance systems, and execute necessary networking activities. Many nonprofits already recognize that strategic management success requires great commitment and effort, can take months to create (Alexander, 2000; Moxley, 2004), and may require organizational discipline to sustain processes with which nonprofits are not accustomed (Maranville, 1999). Further, strategic management also requires managers to spend time networking, motivating, or convincing various stakeholders to contribute to the process. This resource requirement may explain why larger nonprofits are more likely to conduct strategic management, as they may have more resources to allocate.

One approach used to address the required investments for strategic management is by outsourcing much of the process to outside consultants. Smaller NPOs, which may still be led by the original founder, often do not have the appropriate management skills or training to lead organizational strategic management (Alfirevic \& Gabelica, 2007), nor the organizational capacity necessary to dedicate to planning (Brands \& Elam, 2013). Larger NPOs may have more experienced managers and staff, but generally require more advanced or complex strategic processes and may find it more convenient to outsource development rather than shift existing staff members from mission-related activities. 


\section{Miller (2018)}

Outsourcing strategic management to consultants, however, can present risks to NPOs. Consultants are often hired for a defined time period, in which they must develop a strategic process, implement the process, and help train the organization on how to implement and sustain the plan. Once consultants leave, however, it falls upon the organization to stay committed to the process. As managers and staff change, institutional knowledge can be lost. Additionally, external consultants may conduct too much of the planning without the appropriate involvement of key stakeholders, such as boards, funders, or the workforce. If boards and funders are too excluded from planning or processes, they may not have buy-in to the product and can either reject any strategic processes or fail to use them in decision-making. Limiting or failing to involve the workforce may also prevent a strategic management effort from leveraging the experiences and knowledge of those working closely with the organization's customers. When using outside consultants, NPO managers should balance the need to outsource strategic management development with insourcing organizational involvement and commitment to the result.

\section{Hybrid organizations and alternative funding models}

This research uncovered no substantive linkages between nonprofit strategic management and the newly emerging topics of hybrid organizations, including social enterprises, nor the variety of new funding models for third-sector efforts. As this study-similar to the SBC study before-focused only on nonprofit organizations, it is possible that any relevant evidence was purposefully excluded from the review. Similarly, alternative funding models emerging from the growing social enterprise space may have also been excluded, or be too recent to have generated research evidence for this synthesis. Future research may seek to expand the synthesis beyond nonprofits to include social enterprises or hybrid organizations.

\section{CONCLUSION}

This study has examined how nonprofit strategic management has evolved over the past two decades. Nonprofits are experiencing pressure from reduced government funding, increased competition, stakeholder demands for accountability and operational effectiveness, and rapid changes in technological and data access. These forces create uncertainty and expose organizational deficiencies in decision-making, human capital skills, or performance management systems. The findings of this study suggest that NPOs are using strategic management to address uncertainty, mitigate deficiencies, and continue to evolve and adapt strategic content and implementation. Nonprofits that use strategic management can deliver improved results and performance, although risks are present and the relationship between strategic choices and specific outcomes are not yet fully understood. Nonprofits are likely to continue using, evolving, and adapting strategic management to help address uncertainty for the next two decades.

\section{NOTE}

1. There is a rich body of evidence that challenges the appropriateness, usefulness, and effectiveness of strategic management in organizations (see Mintzberg, 1994, or Martin, 2014). This article does not seek to deliberate these points, but in the spirit of advancing previous scholarship on strategic management, instead follows the premise of scholar John Bryson (2011): managers of nonprofits are more likely to determine suitable paths to attaining organizational goals when using a disciplined process of deliberation, namely strategic management.

\section{REFERENCES}

Akingbola, K. (2006). Strategic choices and change in non-profit organizations. Strategic Change, 15(6), 265-281. doi: $10.1002 / j s c .772$

Alexander, J. (2000). Adaptive strategies of nonprofit human service organizations in an era of devolution and new public management. Nonprofit Management \& Leadership, 10(3), 287-303. 


\section{Miller (2018)}

Alfirevic, N., \& Gabelica, N. (2007). Management practices in Croatian non-profit organizations: Results of the empirical research. Management: Journal of Contemporary Management Issues, 12(1), 25-44.

Arvidson, M., \& Lyon, F. (2014). Social impact measurement and non-profit organisations: Compliance, resistance, and promotion. Voluntas: International Journal of Voluntary \& Nonprofit Organizations, 25(4), 869-886. doi: 10.1007 Is11266-013-9373-6

Baruch, Y., \& Ramalho, N. (2006). Communalities and distinctions in the measurement of organizational performance and effectiveness across for-profit and nonprofit sectors. Nonprofit and Voluntary Sector Quarterly, 35(1), 39-65. doi: $10.1177 / 0899764005282468$

Basinger, N.W., \& Peterson, J.R. (2008). Where you stand depends on where you sit: Participation and reactions to change. Nonprofit Management and Leadership, 19(2), 243-257. doi: 10.1002/nml.217

Beck, T.E., Lengnick-Hall, C.A., \& Lengnick-Hall, M.L. (2008). Solutions out of context: Examining the transfer of business concepts to third sector organizations. Nonprofit Management \& Leadership, 19(2), 153-171.

Black, J.A., Hinrichs, K.T., \& Fabian, F.H. (2007). Fractals of strategic coherence in a successful nonprofit organization. Nonprofit Management and Leadership, 17(4), 421-441. doi: 10.1002/nml.161

Bowman, C., \& Asche, D. (1987). Strategic management. London, UK: Macmillan.

Brands, K., \& Elam, D. (2013). Addressing fundraising challenges of a non-profit organization caused by financial uncertainty using an appreciative inquiry approach. South Asian Journal of Business \& Management Cases, 2(2), 163-176. doi: 10.1177/2277977913509166

Brown, W.A., \& Iverson, J.O. (2004). Exploring strategy and board structure in nonprofit organizations. Nonprofit \& Voluntary Sector Quarterly, 33(3), 377-400.

Bryson, J.M. (2011). Strategic planning for public and nonprofit organizations. San Francisco, CA: Wiley \& Sons.

Bryson, J.M., Gibbons, M.J., \& Shaye, G. (2001). Enterprise schemes for nonprofit survival, growth, and effectiveness. Nonprofit Management \& Leadership, 11(3), 271-288.

Canet-Giner, M.T., Fernandez-Guerrero, R., \& Peris-Ortiz, M. (2010). Changing the strategy formulation process in a service cooperative. Journal of Organizational Change Management, 23(4), 435-452. doi: 10.1108/09534811011 055412

Chadwick-Coule, T. (2011). Social dynamics and the strategy process: Bridging or creating a divide between trustees and staff? Nonprofit \& Voluntary Sector Quarterly, 40(1), 33-56.

Chew, C., \& Osborne, S.P. (2009). Identifying the factors that influence positioning strategy in U.K. charitable organizations that provide public services: Toward an integrating model. Nonprofit \& Voluntary Sector Quarterly, 38(1), 29-50.

Courtney, R. Marnoch, G., \& Williamson, A. (2009). Strategic planning and performance: An explanatory study of housing associations in Northern Ireland. Financial Accountability \& Management, 25(1), 55-78. doi: 10.1111 /j.1468-0408.2008.00465.x

Crittenden, W.F. (2000). Spinning straw into gold: The tenuous strategy, funding, and financial performance linkage. Nonprofit \& Voluntary Sector Quarterly, 29(1), 164-182.

Crittenden, W.F., Crittenden, V.L., Stone, M.M., \& Robertson, C.J. (2004). An uneasy alliance: Planning and performance in nonprofit organizations. International Journal of Organizational Theory and Behavior, 7(1), 81-106.

Cronley, C., \& Kim, Y.K. (2014). The path to service quality: The mediating role of organizational commitment on the effects of strategic planning and technology access within the Salvation Army. Human Service Organizations: Management, Leadership \& Governance, 38(1), 74-88. doi: 10.1080/03643107.2013.828006

Dreiling, M., Lougee, N., Jonna, R., \& Nakamura, T. (2008). Environmental organizations and communication praxis: A study of communication strategies among a national sample of environmental organizations. Organization \& Environment, 21(4), 420-445. 


\section{Miller (2018)}

Elsevier, B.V. (2016a). Citation count for "Research on strategic management in nonprofit organizations: Synthesis, analysis, and future directions." URL: https://www.scopus.com [Accessed November 13, 2016].

Elsevier, B.V. (2016b). Field-weighted citation impact for "Research on strategic management $\backslash$ in nonprofit organizations: Synthesis, analysis, and future directions." URL: https://www.scopus.com [Accessed November 13, 2016].

Fine, A.H., Thayer, C.E., \& Coghlan, A.T. (2000). Program evaluation practice in the nonprofit sector. Nonprofit Management \& Leadership, 10(3), 331-339.

Finley, D.S., Rogers, G., Napier, M., \& Wyatt, J. (2011). From needs-based segmentation to program realignment: Transformation of YWCA of Calgary. Administration in Social Work, 35(3), 299-322.

Froelich, K.A. (1999). Diversification of revenue strategies: Evolving resource dependence I nonprofit organizations. Nonprofit and Voluntary Sector Quarterly, 23(3), 246-268.

Gimbert, X., Bisbe, J., \& Mendoza, X. (2010). The role of performance measurement systems in strategy formulation processes. Long Range Planning, 43(4), 477-497.

Golensky, M., \& Mulder, C.A. (2006). Coping in a constrained economy: Survival strategies of nonprofit human service organizations. Administration in Social Work, 30(3), 5-24.

Greiling, D., \& Stötzer, S. (2015). Performance accountability as a driver for changes in nonprofit-government relationships: An empirical insight from Austria. Voluntas: International Journal of Voluntary \& Nonprofit Organizations, 26(5), 1690-1717.

Hackler, D., \& Saxton, G.D. (2007). The strategic use of information technology by nonprofit organizations: Increasing capacity and untapped potential. Public Administration Review, 67(3), 474-487. doi: 10.1111/j.1540-6210.2007 $.00730 . x$

Hafsi, T., \& Thomas, H. (2005). Strategic management and change in high dependency environments: The case of a philanthropic organization. Voluntas: International Journal of Voluntary \& Nonprofit Organizations, 16(4), 329-351.

Harris, M.J. (2011). Strategic planning in an international nongovernmental development organization: The creation of a meta-identity. Administration \& Society, 43(2), 216-247. doi: 10.1177/0095399711400052

Hatten, M.L. (1982). Strategic management in not-for-profit organizations. Strategic Management Journal, 3(1), 89-104.

Herman, R.D., \& Renz, D.O. (1999). Theses on nonprofit organizational effectiveness. Nonprofit and Voluntary Sector Quarterly, 28(2), 107-125.

Hoffman, J.J., Digman, L.A., \& Crittenden, W.F. (1991). The strategic management process in nonprofit organizations with dynamic environments. Journal of Managerial Issues, 3(3), 357-371.

Inglis, S., \& Alexander, T. (1999). Roles and responsibilities of community nonprofit boards. Nonprofit Management \& Leadership, 10(2), 153-167.

Jäger, U., \& Beyes, T. (2010). Strategizing in NPOs: A case study on the practice of organizational change between social mission and economic rationale. Voluntas: International Journal of Voluntary \& Nonprofit Organizations, 21(1), 82-100. doi: 10.1007/s11266-009-9108-x

Kaplan, R.S. (2001). Strategic performance measurement and management in nonprofit organizations. Nonprofit Management \& Leadership, 11(3), 353-370.

Keyt, J.C. (2001). Beyond strategic control: Applying the balanced scorecard to a religious organization. Journal of Nonprofit \& Public Sector Marketing, 8(4), 91-102.

Kong, E. (2008). The development of strategic management in the non-profit context: Intellectual capital in social service non-profit organizations. International Journal Of Management Reviews, 10(3), 281-299. doi: 10.1111/j.1468-2370.2007.00224.x

Krug, K., \& Weinberg, C.B. (2004). Mission, money, and merit: Strategic decision making by nonprofit managers. Nonprofit Management \& Leadership, 14(3), 325-342.

LeRoux, K., \& Wright, N.S. (2010). Does performance measurement improve strategic decision making? Findings from a national survey of nonprofit social service agencies. Nonprofit \& Voluntary Sector Quarterly, 39(4), 571-587. 


\section{Miller (2018)}

Mahmoud, M.A., \& Yusif, B. (2012). Market orientation, learning orientation, and the performance of nonprofit organizations (NPOs). International Journal of Productivity \& Performance Management, 61(6), 624-652. doi: $10.1108 / 1741040121124919$

Mara, C.M. (2000). A strategic planning process for a small nonprofit organization. Nonprofit Management \& Leadership, 11(2), 211-223.

Maranville, S.J. (1999). Requisite variety of strategic management modes: A cultural study of strategic actions in a deterministic environment. Nonprofit Management \& Leadership, 9(3), 277-291.

Marlin, D., Geiger, S.W., \& Ritchie, W.J. (2013). The hospital foundation strategy and performance relationship. Nonprofit Management \& Leadership, 23(4), 427-441.

Marlin, D., Ritchie, W.J., \& Geiger, S.W. (2009). Strategic group membership and nonprofit organization performance. Nonprofit Management \& Leadership, 20(1), 23-39.

Martin, R. L. (2014). The big lie of strategic planning. Harvard Business Review, 92(1/2), 78-84.

McHatton, P.A., Bradshaw, W., Gallagher, P.A., \& Reeves, R. (2011). Results from a strategic planning process: Benefits for a nonprofit organization. Nonprofit Management and Leadership, 22(2), 233-249.

McMurtry, S.L., Netting, F.N., \& Kettner, P.M. (1991). How nonprofits adapt to a stringent environment. Nonprofit Management and Leadership, 1(3), 235-252.

Medley, B.C., \& Akan, O.H. (2008). Creating positive change in community organizations: A case for rediscovering Lewin. Nonprofit Management \& Leadership, 18(4), 485-496.

Meerman, R.J., \& Huyser, M. (2014). Organizational strategy in a gentrifying neighborhood. Human Service Organizations: Management, Leadership \& Governance, 38(5), 448-458.

Mintzberg, H. (1994). The rise and fall of strategic planning: Reconceiving roles for planning, plans, planners. New York, NY: Free Press.

Moxley, D.P. (2004). Factors influencing the successful use of vision-based strategy planning in nonprofit human service organizations. International Journal of Organization Theory and Behavior, 7(1), 107-132.

Netting, F.E., Williams, F.G., \& Hyer, K. (1998). Resource centers: A foundation's strategy to support nonprofit grantees. Nonprofit Management \& Leadership, 8(3), 261-274.

Neville, L., \& Murray, E.J. (2008). Succession, strategy, culture, and change at Santropol Roulant. Nonprofit Management \& Leadership, 19(1), 107-121. doi: 10.1002/nml.208

Olsen, M.D., Tse, E.C.Y, \& West, J.J. (2008). Strategic management in the hospitality industry [3 ${ }^{\text {rd }}$ ed.]. Upper Saddle River, NJ: Pearson Prentice-Hall.

Papadimitriou, D. (2007). Conceptualizing effectiveness in a non-profit organizational environment: An exploratory study. International Journal of Public Sector Management, 20(7), 571-587. doi: 10.1108/09513550710823498

Pietroburgo, J., \& Wernet, S.P. (2004). Joining forces, fortunes, and futures: Restructuring and adaptation in nonprofit hospice organizations. Nonprofit Management \& Leadership, 15(1), 117-137.

Pijl, K.v.d., \& Sminia, H. (2004). Strategic management of public interest organizations. Voluntas: International Journal of Voluntary \& Nonprofit Organizations, 15(2), 137-155.

Pope, J.A., Isely, E.S., \& Asamoa-tutu, F. (2009). Developing a marketing strategy for nonprofit organizations: An exploratory study. Journal of Nonprofit \& Public Sector Marketing, 21(2), 184-201.

Pritchard, D., Ogain, E., \& Lumley, T. (2012). Making an impact: Impact measurement among charities and social enterprises in the UK. London, UK: New Philanthropy Capital.

Samuel, O., Wolf, P., \& Schilling, A. (2013). Corporate volunteering: Benefits and challenges for nonprofits. Nonprofit Management and Leadership, 24(2), 163-179. doi: 10.1002/nml.21089

Sharp, Z., \& Brock, D.M. (2012). Implementation through risk mitigation: Strategic processes in the nonprofit organization. Administration \& Society, 44(5), 571-594. doi: 10.1177/0095399711418325 
Miller (2018)

Shea, M., \& Hamilton, R.D. (2015). Who determines how nonprofits confront uncertainty? Nonprofit Management \& Leadership, 25(4), 383-401. doi: 10.1002/nml.21136

Sheehan, R.M., Jr. (1999). Achieving growth and high quality by strategic intent. Nonprofit Management \& Leadership, 9(4), 413-428.

Shortell, S.M., Morrison, E.M., \& Robbins, S. (1985). Strategy making in health care organizations: A framework and agenda for research. Medical Care Review, 42(2), 219-266.

Stater, K.J. (2009). The impact of revenue sources on marketing behavior: Examining web-promotion and placemarketing in nonprofit organizations. Journal of Nonprofit \& Public Sector Marketing, 21(2), 202-224. doi: 10.1080/10495140802529540

Stone, M.M., Bigelow, B.B., \& Crittenden, W. (1999). Research on strategic management in nonprofit organizations: Synthesis, analysis, and future directions. Administration \& Society, 31(3), 378-423.

Swanson, L.A. (2013). A strategic engagement framework for nonprofits. Nonprofit Management \& Leadership, 23(3), 303-323. doi: $10.1002 / \mathrm{nml} .21067$

Thomas, J., \& Harden, A. (2008). Methods for the thematic synthesis of qualitative research in systematic reviews. BMC Medical Research Methodology, 8(45), 1-10. doi: 10.1186/1471-2288-8-45

Tucker, B.P., \& Parker, L.D. (2013). Managerial control and strategy in nonprofit organizations: Doing the right things for the wrong reasons? Nonprofit Management \& Leadership, 24(1), 87-107.

Tucker, B.P., Thorne, H., \& Gurd, B.W. (2013). Uncharted waters: Exploring the relationship between strategy processes and management control systems in the nonprofit sector. Nonprofit Management \& Leadership, 24(1), 109-133.

Wollebaek, D. (2009). Survival in local voluntary associations. Nonprofit Management \& Leadership, 19(3), 267-284.

\section{ABOUT THE AUTHOR / L'AUTEUR}

Eric W. Miller works in the U.S. government and is an Adjunct Professor at George Mason University, 400 University Dr., Fairfax, VA 22030. Email: emille2@gmu.edu . 
Miller (2018)

\title{
APPENDIX A: \\ Journals included, 1998-2015
}

\author{
Administration \& Society \\ Administration in Social Work \\ Asian Business Review \\ Financial Accountability \& Management \\ Human Service Organizations: Management, Leadership \& Governance \\ International Journal of Management Reviews \\ International Journal of Organizational Theory \& Behavior \\ International Journal of Productivity \& Performance Management \\ International Journal of Public Sector Management \\ Journal of Nonprofit \& Public Sector Marketing \\ Journal of Organizational Change Management \\ Long Range Planning \\ Management: Journal of Contemporary Management Issues \\ Nonprofit \& Voluntary Sector Quarterly \\ Nonprofit Management \& Leadership \\ Organization \& Environment \\ Public Administration Review \\ South Asian Journal of Business \& Management Cases \\ Strategic Change \\ Voluntas:International Journal of Voluntary \& Nonprofit Organizations
}

